\title{
PEMAKAIAN ALAT PELINDUNG DIRI PADA TENAGA PERAWAT DAN BIDAN DI RUMAH SAKIT PELITA INSANI
}

\author{
Tien Zubaidah, Arifin, Yudha Afiat Jaya \\ Jurusan Kesehatan Lingkungan Poltekkes Kemenkes Banjarmasin \\ Jl.H.M.Cokrokusumo No.1A Kota Banjarbaru \\ Email: arrasyid.hanif@gmail.com
}

\begin{abstract}
The use personal protective equipment on nurses and midwifes in Pelita Insani's Hospital. The hospital is an institution and public services working in the field of health services with the use of equipment high technology, materials, and medicines are harmful to health for diagnostic measures, therefore, exposure of medical personnel at the hospital against hazardous materials and seedling diseases have a high risk to the health status of health personnel. The purpose of this research was to gain an overview of the use of personal protective equipment on nurses and midwifes in Pelita Insani's hospital, Martapura.

The study was an observational cross-sectional study design, namely direct observation on the application of the use of personal protective equipment in Pelita Insani's hospital, Martapura then analyzed based on the theories and regulations. This study did not use sampling or total population of as many as 48 nurses and midwifes in Pelita Insani' hospital, Martapura.

The results showed the male sex more is not better in terms the use of personal protective equipment (66.67\%), 56.52\% of nurses and midwifes in the age range $20-27$ years was not good in terms of the use of personal protective equipment . Level of education, length of service and length of employment showed $58.33 \%$ was not good in terms of the use of personal protective equipment. The nurses were not good in terms of the use of personal protective equipment (62.07\%). Availability of personal protective equipment in Pelita Insani's hospital, Martapura already available enough for all nurses and midwifes. The need for counseling are scheduled on a regular basis about the benefits of personal protective equipment to increase self-awareness of nurses and midwives and accompanied with strict supervision.
\end{abstract}

Keywords: Personal Protective Equipment, nurses and midwifes, hospital

\begin{abstract}
Abstrak: Pemakaian APD pada tenaga perawat dan bidan di Rumah Sakit Pelita Insani. Rumah sakit adalah institusi pelayanan masyarakat yang bergerak di bidang pelayanan jasa kesehatan dengan penggunaan peralatan tekhnologi tinggi, bahan-bahan, dan obat-obatan berbahaya bagi kesehatan untuk tindakan diagnostik, oleh karena itu, terpaparnya tenaga kesehatan di rumah sakit terhadap bahan-bahan berbahaya dan bibit penyakit mempunyai resiko tinggi terhadap status kesehatan tenaga kesehatan. Tujuan dalam penelitian ini adalah untuk memperoleh gambaran tentang pemakaian APD pada tenaga perawat dan bidan di RS Pelita Insani Martapura. Jenis penelitian adalah observasional dengan desain penelitian cross sectional yaitu melakukan pengamatan langsung mengenai penerapan APD di RS Pelita Insani Martapura kemudian dianalisis berdasarkan teori-teori dan peraturan yang berlaku. Penelitian ini tidak menggunakan sampling atau total populasi berjumlah sebanyak 48 orang tenaga perawat dan bidan di RS Pelita Insani Martapura. Hasil penelitian menunjukkan jenis kelamin laki-laki lebih banyak tidak baik dalam hal pemakaian APD (66,67\%). 56,52\% tenaga perawat dan bidan dalam rentang umur 20-27 tahun tidak baik dalam hal pemakaian APD. Tingkat pendidikan, masa kerja dan lama kerja menunjukkan 58,33\% tidak baik dalam hal pemakaian APD. Profesi yang tidak baik dalam hal pemakaian APD yaitu tenaga perawat $(62,07 \%)$. Ketersediaan APD di RS Pelita Insani Martapura sudah tersedia cukup untuk semua tenaga perawat dan bidan. Perlu adanya penyuluhan yang terjadual secara rutin tentang manfaat APD untuk meningkatkan kesadaran diri tenaga perawat dan bidan serta diiringi dengan pengawasan yang ketat.
\end{abstract}

Kata Kunci : : Alat Pelindung Diri (APD), tenaga perawat dan bidan, Rumah sakit 


\section{PENDAHULUAN}

Rumah sakit adalah industri yang bergerak dibidang pelayanan jasa kesehatanyang tujuan utamanya memberikan pelayanan jasa terhadap masyarakat sebagai usaha meningkatkan derajat kesehatan yang setingggi-tingginya. Di samping memberikan dampak positif, faktor tersebut juga memberikan nilai negatif terhadap semua komponen yang terlibat dalam proses pelayanan kesehatan yang berakhir dengan timbulnya kerugian(1).

Bahaya-bahaya lingkungan kerja baik fisik, biologis maupun kimiawi perlu dikendalikan sedemikian rupa sehingga tercipta suatu lingkungan kerja yang sehat, aman, dan nyaman. Berbagai cara pengendalian dapat dilakukan untuk menanggulangi bahaya-bahaya lingkungan kerja, namun pengendalian secara teknis pada sumber bahaya itu sendiri dinilai paling efektif dan merupakan alternatif pertama yang dianjurkan, sedangkan pemakaian Alat Pelindung Diri (APD) merupakan pilihan terakhir. Salah satu upaya dalam rangka pemberian perlindungan tenaga kerja terhadap Keselamatan dan Kesehatan Kerja (K3) di rumah sakit adalah dengan cara memberikan APD. Pemberian APD kepada tenaga kerja, merupakan upaya terakhir apabila upaya rekayasa (engineering) dan cara kerja yang aman (work practices) telah maksimum dilakukan(2).

Laporan-laporan rumah sakit di Indonesia yang menunjukkan terjadinya infeksi nosokomial di beberapa rumah sakit adalah di RS Hasan Sadikin Bandung 9,9\%, di RS Pirngadi Medan 13,92\%, RS. Karyadi Semarang 7,3\%, Dr. Soetomo Surabaya 5,32 dan RSCM 5,4 \% (3).

Infeksi nosokomial merupakan salah satu risiko kerja yang dihadapi oleh tenaga kesehatan di rumah sakit.Darah dan cairan tubuh merupakan media penularan penyakit dari pasien kepada tenaga kesehatan. Human Immunodeficiency Virus (HIV), Hepatitis B dan Virus Hepatitis C merupakan ancaman terbesar pada tenaga kesehatan. Pada tahun 2002, WHO memperkirakan terjadi 16.000 kasus penularan virus hepatitis C, 66.000 kasus penularan hepatitis B dan 1.000 kasus penularan HIV pada tenaga kesehatan di seluruh dunia dan Infeksi nosokomial banyak terjadi di seluruh dunia dengan kejadian terbanyak di negara miskin dan negara yang sedang berkembang karena penyakit-penyakit infeksi masih menjadi penyebab utama. Suatu penelitian yang dilakukan oleh WHO menunjukkan bahwa sekitar $8.7 \%$ dari 55 rumah sakit dari 14 negara di Eropa, Timur tengah, dan Asia Tenggara dan Pasifik terdapat infeksi nosokomial dengan Asia Tenggara sebanyak $10 \%(4)$

Penelitian Anwar dan Perwitasari (2006) ${ }^{(5)}$ menginformasikan bahwa pemakaian APD dari 4 laboratorium yang ada di RSUPN Cipto Mangunkusumo, ternyata lebih dari $40 \%$ petugas di 3 laboratorium (IGD, Hematologi dan anak) berisiko terinfeksi penyakit berbahaya seperti HIV/AIDS.

Pemerintah melalui kementerian kesehatan mencanangkan program Pencegahan dan Pengendalian Infeksi (PPI), dalam bentuk patient safety. Tujuan dari program PPI adalah untuk meningkatkan kualitas pelayanan rumah sakit dan fasilitas kesehatan lainnya melalui pencegahan dan pengendalian infeksi, melindungi sumber daya manusia kesehatan dan masyarakat dari penyakit infeksi yang berbahaya, serta menurunkan angka kejadian Infeksi Nosokomial(6). Kebijakan ini tertuang dalam Kepmenkes Nomor 82/2007 tentang pedoman pencegahan infeksi di rumah sakit.

Fenomena yang terjadi ternyata pemakaian APD belum sepenuhnya dapat berjalan sesuai dengan prosedur. Berdasarkan hasil survei pendahuluan di salah satu rumah sakit swasta di Kalimantan Selatan ditemukan tenaga kesehatan yang dalam beraktifitas di RS tidak memakai APD. Penelitian lebih lanjut tentang pemakaian APD pada tenaga kesehatan khususnya tenaga perawat dan bidan menarik untuk diteliti.

Berdasarkan latar belakang di atas, dilakukan kegiatan observasi dan penelitian untuk mengetahui pemakaian alat APD pada tenaga perawat dan bidan di RS Pelita Insani Martapura. Penelitian ini 
memberikan gambaran tentang karakteristik tenaga perawat dan bidan meliputi umur, pendidikan, lama kerja dan masa kerja, macam APD yang tersedia dan mengidentifikasi penggunaan APD di RS Pelita Insani Martapura.

\section{BAHAN DAN CARA PENELITIAN}

Desain penelitian adalah observasional dengan menggunakan studi cross sectional. Penelitian dilakukan di RS Pelita Insani Martapura Kabupaten Banjar Kalimantan Selatan pada bulan Februari Juni 2014. Populasi dalam penelitian ini adalah semua tenaga perawat dan bidan yang bertugas di RS Pelita Insani Martapura. Penelitian ini tidak menggunakan sampling atau total populasi berjumlah sebanyak 48 orang.Variabel yang diteliti dalam penelitian ini meliputi karakteristik tenaga perawat dan bidan, macam APD dan pemakaian APD.

Pengumnpulan data diperoleh melalui wawancara dengan menggunakan kuesioner di bagian ruang lingkup kerja tenaga perawat dan bidan. Pada penelitian ini juga dilakukan pengamatan langsung/observasi dengan menggunakan panduan observasi pemakaian APD di rumah sakit. Data yang telah terkumpul kemudian diolah secara manual, dianalisis secara deskriptif dan dibandingkan dengan teori-teori yang berhubungan dengan penelitian.

\section{HASIL DAN PEMBAHASAN}

1. Karakteristik Tenaga Perawat dan bidan

a. Jenis Kelamin

Jumlah tenaga perawat dan bidan di Pelita Insani ada sebanyak 48 orang, dapat dilihat pada tabel 1.

Tabel 1 Jumlah Tenaga Perawat dan bidan di RS Pelita Insani Martapura Tahun 2014 Berdasarkan Jenis Kelamin

\begin{tabular}{cccc}
\hline No & $\begin{array}{c}\text { Jenis } \\
\text { Kelamin }\end{array}$ & $\begin{array}{c}\text { Jumlah } \\
\text { (orang) }\end{array}$ & Persentasi \\
\hline 1. & Laki-laki & 12 & $25 \%$ \\
2. & Perempuan & 36 & $75 \%$ \\
\hline & Jumlah & $\mathbf{4 8}$ & $\mathbf{1 0 0 \%}$ \\
\hline
\end{tabular}

Hasil penelitian menunjukan yang berjenis kelamin laki-laki sebanyak 12 responden (25\%) dan perempuan 36 responden $(75 \%)$. Hal ini berarti tenaga kerja yang berjenis kelamin perempuan lebih banyak daripada laki-laki dengan distribusi tenaga perawat sebanyak 29 orang dan bidan sebanyak 19 orang.

b. Umur

Umur tenaga kerja adalah berkisar antara 20 - 27 tahun. Untuk lebih jelasnya dapat dilihat pada tabel 2

Tabel 2 Jumlah Tenaga Perawat dan bidan di RS Pelita Insani Martapura Tahun 2014 Berdasarkan Umur

\begin{tabular}{clcc}
\hline No & $\begin{array}{c}\text { Kelompok } \\
\text { umur (thn) }\end{array}$ & $\begin{array}{c}\text { Jumlah } \\
\text { (orang) }\end{array}$ & Persentasi \\
\hline 1. & $20-27$ & 46 & $95,83 \%$ \\
2. & $28-35$ & 2 & $4,17 \%$ \\
\hline & Jumlah & $\mathbf{4 8}$ & $\mathbf{1 0 0 \%}$ \\
\hline
\end{tabular}

Berdasarkan tabel 2 dapat dilihat bahwa rentang umur tenaga perawat dan bidan yang ada di RS Pelita Insani Martapura berkisar antara 20 - 27 tahun $(95,83 \%)$.

c. Tingkat Pendidikan

Tenaga perawat dan bidan di RS Pelita Insani Martapura menurut tingkat pendidikannya seluruh tenaga kerja memiliki pendidikan tinggi yaitu Diploma 3.

Tingkat pendidikan sangat berkaitan dengan cara berfikir yang dapat mempengaruhi pemakaian alat pelindung diri oleh tenaga kerja, seperti cara berpikir dalam menghadapi pekerjaan, menerima latihan kerja dan juga cara menghindari kecelakaan kerja. intervensi pendidikan adalah memotivasi dan memampukan pekerja untuk mengambil tindakan yang efektif dalam meningkatkan kondisi kerja.

d. Masa Kerja

Tenaga perawat dan bidan yang bekerja di RS Pelita Insani Martapura seluruhnya adalah tenaga perawat dan bidan baru yang masa kerjanya $6-12$ bulan, hal ini dikarenakan RS yang baru didirikan.

e. Lama Kerja

Menurut lama kerja untuk tenaga perawat dan bidan yang bekerja di RS Pelita Insani Martapura tahun 2014 masingmasing tenaga kerja memiliki lama kerja sebanyak 8 jam/hari. 


\section{Macam APD}

Macam APD di RS Pelita Insani tersedia masker, sarung tangan, jas operasi, tudung/topi, penutup alas kaki, kacamata operasi, baju pelindung serta sesuai jumlah tenaga perawat dan bidan.

Alat pelindung diri harus tersedia dan sesuai faktor risiko.Macam APD di RS Pelita Insani yang tersedia adalah masker, sarung tangan, jas operasi, tudung/topi, penutup alas kaki, kacamata operasi. Macam APD yang tersedia sudah sesuai dengan setiap ruangannya, kecuali ruang PICU yang masih belum menerapkan APD. Ruang PICU sendiri belum menerapkan APD karena bangunannya masih terlalu sempit dan kecil, dan rencananya setelah bangunan yang baru selesai ruangan ini baru menerapkan APD di ruang tersebut.

Dalam UU No 1 Tahun 1970 pasal 14

butir menyatakan bahwa pengurus (pengusaha) diwajibkan untuk menyediakan secara cuma-cuma seluruh Alat Pelindung Diri yang diwajibkan kepada tenaga perawat dan bidan yang bekerja di bawah pimpinannya dan menyediakan bagai orang lain yang memasuki tempat kerja tersebut, disertai dengan petunjukpetunjuk yang diperlukan menurut petunjuk pegawai pengawas atau ahli-ahli keselamatan kerja. Ketersediaan APD di tempat kerja harus menjadi perhatian managemen perusahaan dan pekerja untuk mendorong terjadinya perubahan sikap pekerja. Semua fasilitas alat pelindung diri yang diwajibkan terhadap tenaga perawat dan bidan. Alat pelindung diri harus tersedia sesuai dengan faktor risiko bahaya yang ada di tempat kerja.

Tabel 3 Jenis APD berdasarkan Ruangan di RS Pelita Insani Martapura Tahun 2014

\begin{tabular}{clcccccc}
\hline \multirow{2}{*}{ No } & \multirow{2}{*}{ Jenis APD } & \multicolumn{7}{c}{ Ruangan } \\
\cline { 2 - 7 } & ICU & NICU & PICU & OK & VK & IGD \\
\hline 1. & Baju pelindung & $\sqrt{ }$ & $\sqrt{ }$ & & & & \\
2. & Sarung tangan & $\sqrt{ }$ & $\sqrt{ }$ & $\sqrt{ }$ & $\sqrt{ }$ & $\sqrt{ }$ & $\sqrt{ }$ \\
3. & Masker & $\sqrt{ }$ & $\sqrt{ }$ & $\sqrt{ }$ & $\sqrt{ }$ & $\sqrt{ }$ & $\sqrt{ }$ \\
4. & Jas operasi & & & & $\sqrt{ }$ & $\sqrt{ }$ & \\
5. & Tudung/topi & & & & $\sqrt{ }$ & $\sqrt{ }$ & \\
6. & Alas kaki & & & & $\sqrt{ }$ & $\sqrt{ }$ \\
7. & Kacamata & & & & $\sqrt{ }$ & $\sqrt{ }$ \\
& operasi & & & & & & \\
\hline
\end{tabular}

\section{Penggunaan APD}

Hampir seluruh tenaga perawat dan bidan di RS Pelita Insani menggunakan APD, yang sesuai untuk faktor risiko fisik yaitu masker dan sarung tangan, untuk faktor risiko fisik lainnya penggunaan APD pada tenaga perawat dan bidan disesuaikan dengan keadaan saat bekerja, seperti pada ruang-ruang sebagai berikut:

Tabel 4 Jumlah Tenaga Perawat dan bidan di RS Pelita Insani Martapura Tahun $2014 \quad$ Berdasarkan Penggunaan APD

\begin{tabular}{clcc}
\hline No & $\begin{array}{c}\text { Penggunaan } \\
\text { APD }\end{array}$ & $\begin{array}{c}\text { Jumlah } \\
\text { (orang) }\end{array}$ & $\begin{array}{c}\text { Persentasi } \\
\text { (\%) }\end{array}$ \\
\hline 1 & Menggunakan & 20 & $41,67 \%$ \\
2 & Tidak & 28 & $58,33 \%$ \\
\hline & Menggunakan & 28 & $\mathbf{1 0 0 \%}$ \\
\hline & $\quad$ Jumlah & $\mathbf{4 8}$ & $\mathbf{1}$
\end{tabular}

Berdasarkan tabel 4 dapat dilihat bahwa di RS Pelita Insani masih terdapat tenaga perawat dan bidan yang tidak menggunakan APD sebanyak 28 orang $(58,33 \%)$.

Alat pelindung diri harus digunakan oleh tenaga kerja setiap bekerja sesuai dengan faktor risiko. Apabila tenaga kerja tidak selalu memakai APD dalam bekerja, maka kemungkinan kecelakaan akibat kerja dan penyakit akibat kerja akan terjadi.

Dari hasil observasi, terdapat tenaga perawat dan bidan yang bekerja di RS Pelita Insani yang menggunakan APD selama bekerja terdapat 20 orang $(41,67 \%)$, yang tidak menggunakan APD selama bekerja sebanyak 28 orang (58,33\%). Pemakaian alat pelindung diri (sarung tangan dan masker) yang tidak selalu digunakan. 
Kondisi ini dapat menyebabkan mereka berpotensi tertular penyakit.

Perilaku manusia dapat digolongkan menjadi dua kategori, yaitu perilaku yang terwujud sengaja atau sadar dan perilaku yang disengaja atau tidak disengaja memberikan manfaat bagi diri individu yang melakukuan perilaku tersebut maupun masyarakat. Perilaku yang disengaja atau tidak disengaja merugikan bagi diri individu yang melakukuan perilaku tersebut maupun masyarakat.

Penelitian ini sesuai dengan pernyataan dalam buku Institution of Occupational Safety and Health (IOSH)(7) bahwa penyebab kecelakaan yang pernah terjadi sampai saat ini adalah diakibatkan oleh perilaku yang tidak aman yaitu, tidak hati-hati, tidak mematuhi peraturan, tidak mengikuti standar prosedur kerja, tidak memakai alat pelindung diri dan kondisi badan yang lemah. Persentase penyebab kecelakaan kerja yaitu 3\% dikarenakan sebab yang tidak bisa dihindarkan (seperti bencana alam), selain itu 24\% dikarenakan lingkungan atau peralatan yang tidak memenuhi syarat dan $73 \%$ dikarenakan perilaku yang tidak aman.

\section{Meningkatkan}

kesadaran, meningkatkan pengetahuan, mengubah sikap, mengubah perilaku dan menurunkan risiko merupakan urutan kompleksitas kebutuhan dan tujuan mulai dari sederhana hingga yang paling komplek dan tidak selalu berhubungan sebab akibat antara yang satu dengan yang lain dan bukan merupakan urutan kejadian(8).

4. Identifikasi Antar Variabel

Tabel 5 Identifikasi Jenis Kelamin dengan Pemakaian APD pada Tenaga Perawat dan bidan di RS Pelita Insani Martapura Tahun 2014

\begin{tabular}{|c|c|c|c|c|c|c|c|}
\hline \multirow{3}{*}{ No } & \multirow{3}{*}{ Jenis Kelamin } & \multicolumn{4}{|c|}{ Pemakaian APD } & \multirow{2}{*}{\multicolumn{2}{|c|}{ Jumlah }} \\
\hline & & \multicolumn{2}{|c|}{ Baik } & \multicolumn{2}{|c|}{ Tidak Baik } & & \\
\hline & & $\mathbf{N}$ & $\%$ & $\mathbf{n}$ & $\%$ & $\mathbf{n}$ & $\%$ \\
\hline 1. & Laki-laki & 4 & 33,33 & 8 & 66,67 & 12 & 100 \\
\hline 2. & Perempuan & 16 & 44,44 & 20 & 55,56 & 36 & 100 \\
\hline & Jumlah & 20 & 41,67 & 28 & 58,33 & 48 & 100 \\
\hline
\end{tabular}

Berdasarkan tabel 5 dapat dilihat bahwa di RS Pelita Insani tenaga perawat dan bidan dengan jenis kelamin perempuan yaitu 20 orang $(55,56 \%)$ yang tidak baik dalam hal pemakaian APD.

Dalam penggunaan APD perempuan yang lebih cenderung tidak baik, hal ini juga disebabkan karena memang lebih banyak tenaga perawat dan bidan perempuan daripada laki-laki, namun untuk keselamatan kerja sendiri, tidak mutlak dipengaruhi oleh jenis kelamin, melainkan kepatuhan dan kedisiplinan tenaga perawat dan bidan akan keselamatan saat bekerja terhadap resiko sekecil apapun.

Tabel 6 Identifikasi Umur dengan Pemakaian APD pada Tenaga Perawat dan bidan di RS Pelita Insani Martapura Tahun 2014

\begin{tabular}{|c|c|c|c|c|c|c|c|}
\hline \multirow{3}{*}{ No } & \multirow{3}{*}{ Umur } & \multicolumn{4}{|c|}{ Pemakain APD } & \multirow{2}{*}{\multicolumn{2}{|c|}{ Jumlah }} \\
\hline & & \multicolumn{2}{|c|}{ Baik } & \multicolumn{2}{|c|}{ Tidak Baik } & & \\
\hline & & n & $\%$ & n & $\%$ & n & $\%$ \\
\hline 1. & $20-27$ & 20 & 43,48 & 26 & 56,52 & 46 & 100 \\
\hline 2. & $28-35$ & 0 & 0 & 2 & 100 & 2 & 100 \\
\hline & Jumlah & 20 & 41,67 & 28 & 58,33 & 48 & 100 \\
\hline
\end{tabular}

Berdasarkan tabel 6 dapat dilihat bahwa tenaga perawat dan bidan dengan 
rentang umur 20 - 27 tahun sebanyak 26 orang $(56,52 \%)$ yang tidak baik dalam hal pemakaian APD.

Hasil penelitian yang dilakukan di Amerika Serikat menyebutkan, bahwa usia muda mempunyai risiko kecelakaan lebih tinggi bila dibandingkan dengan yang berusia tua(7). Ini bisa dimengerti karena tingginya risiko celaka pada usia muda biasanya disebabkan oleh mobilitas kerja yang lebih tinggi, sehingga kurang berhatihati dalam melakukan pekerjaan.

Menurut Suwita, 2001 dalam Mulyanti, 2008(9) yang mengutip pendapat Gilmer bahwa pengaruh antara umur terhadap performance kerja dan seterusnya akan berkaitan dengan tingkat kinerja. Mereka yang berusia lebih tua cenderung mempunyai pengalaman untuk mengantisipasi terhadap kemungkinan bahaya dari tidak memakai APD dibandingkan dengan usia muda dalam melaksanakan pekerjaannya.

Tenaga perawat dan bidan di RS Pelita Insani Martapura seluruhnyamemiliki pendidikan yang sama yaitu jenjang Diploma 3. Dalam hal pemakaian APD sebanyak $41,67 \%$ dan $58,33 \%$ tidak menggunakan APD dalam bekerja.

Notoadmodjo (2003)(10), menyebutkan pendidikan dapat mempengaruhi seseorang termasuk juga perilaku seseorang akan pola hidup terutama dalam memotivasi untuk sikap berperan serta dalam pembangunan(11), pada umumnya semakin tinggi pendidikan akan mempermudah menerima informasi dari informasi yang akan diperoleh akan menghasilkan pengetahuan yang baik, sedangkan semakin baik pengetahuan seseorang akan mempengaruhi seseorang untuk berperilaku baik.

Hasil penelitian yang dilakukan Christina Anugrahini di RSAB Harapan Kita Jakarta tahun 2010 menyatakan bahwa ada hubungan yang erat antara pendidikan dengan kepatuhan perawat dalam pemakaian APD ${ }^{(12) .}$

Tabel 7 Identifikasi Masa Kerjadengan Penggunaan APD pada Tenaga Perawat dan bidan di RS Pelita Insani Martapura Tahun 2014

\begin{tabular}{cccccccc}
\hline \multirow{2}{*}{ No } & \multirow{2}{*}{ Masa Kerja } & \multicolumn{3}{c}{ Penggunaan APD } & \multicolumn{2}{c}{ Jumlah } \\
\cline { 3 - 7 } & & \multicolumn{2}{c}{ Baik } & \multicolumn{2}{c}{ Tidak Baik } & \multicolumn{2}{c}{} \\
\cline { 2 - 7 } & n & $\mathbf{\%}$ & n & $\mathbf{\%}$ & n & \% \\
\hline 1. & $6-12$ bulan & 20 & 41,67 & 28 & 58,33 & 48 & 100 \\
\hline & Jumlah & $\mathbf{2 0}$ & $\mathbf{4 1 , 6 7}$ & $\mathbf{2 8}$ & $\mathbf{5 8 , 3 3}$ & $\mathbf{4 8}$ & $\mathbf{1 0 0}$ \\
\hline
\end{tabular}

Berdasarkan tabel 7 dapat dilihat bahwa tenaga perawat dan bidan di RS Pelita Insani dalam penggunaan APD berdasarkan masa kerja 6 - 12 bulan yaitu sebanyak 28 orang $(58,33 \%)$ penggunaan APD tidak baik dan sebanyak 20 orang $(41,67 \%)$ penggunaan APD baik.

Tenaga perawat dan bidan yang bekerja pada RS Pelita Insani memiliki masa kerja yang masih 6-12 bulan yang membedakan hanya dalam hitungan bulan, hal ini dikarenakan RS ini sendiri baru dibangun. Oleh karena itu dari 48 orang responden semua masih dalam kategori baru yaitu sebanyak 100\%.Dalam penggunaan APD masa kerja tidak berpengaruh, hal ini dikarenakan masa kerja yang lama ataupun baru secara psikologis tidak akan mempengaruhi penggunaan APD. Tetapi untuk keselamatan kerja sendiri, tidak mutlak dipengaruhi oleh masa kerja, melainkan kepatuhan dan kesadaran diri tenaga perawat dan bidan akan keselamatan saat bekerja terhadap resiko sekecil apapun.

Anderson (1974)(13) menyebutkan bahwa seseorang yang sudah lama bekerja mempunyai wawasan yang lebih luas dan pengalaman yang lebih banyak yang akan berperan dalam perilaku tenaga kerja. Secara psikologis tenaga kerja dengan masa kerja yang lama merasa berpengalaman dengan pekerjaannya dan menganggap pekerjaannya adalah suatu rutinitas seharihari, sehingga penggunaan APD tidak lagi menjadi ketentuan yang harus dilakukan. 
Tabel 8 Identifikasi Lama Kerjadengan Penggunaan APD pada Tenaga Perawat dan bidan di RS Pelita Insani Martapura Tahun 2014

\begin{tabular}{|c|c|c|c|c|c|c|c|}
\hline \multirow{3}{*}{ No } & \multirow{3}{*}{ Lama Kerja } & \multicolumn{4}{|c|}{ Penggunaan APD } & \multirow{2}{*}{\multicolumn{2}{|c|}{ Jumlah }} \\
\hline & & \multicolumn{2}{|c|}{ Baik } & \multicolumn{2}{|c|}{ Tidak Baik } & & \\
\hline & & $\mathbf{n}$ & $\%$ & $\mathbf{n}$ & $\%$ & $\mathbf{n}$ & $\%$ \\
\hline 1. & Sesuai & 20 & 41,67 & 28 & 58,33 & 48 & 100 \\
\hline & Jumlah & 20 & 41,67 & 28 & 58,33 & 48 & 100 \\
\hline
\end{tabular}

Berdasarkan tabel 8 dapat dilihat bahwa tenaga perawat dan bidan di RS Pelita Insani masih terdapat yang tidak baik dalam penggunaan APD berdasarkan lama kerja yaitu sebanyak 28 orang (58,33\%), sedangkan yang dalam penggunaan APD baik sebanyak 20 orang $(41,67 \%)$.
Hasil penelitian yang dilakukan Dona Riska Madyanti di RSUD Bengkalis tahun 2011 dalam Mulyanti, 2008, menyatakan bahwa lama seseorang bekerja tidak berpengaruh dengan kepatuhan dalam hal pemakaian $\operatorname{APD}^{(9)}$.

Tabel 9 Identifikasi Profesi dengan Pemakaian APD pada Tenaga Perawat dan bidan di RS Pelita Insani Martapura Tahun 2014

\begin{tabular}{|c|c|c|c|c|c|c|c|}
\hline \multirow{3}{*}{ No } & \multirow{3}{*}{ Profesi } & \multicolumn{4}{|c|}{ Penggunaan APD } & \multirow{2}{*}{\multicolumn{2}{|c|}{ Jumlah }} \\
\hline & & \multicolumn{2}{|c|}{ Baik } & \multicolumn{2}{|c|}{ Tidak Baik } & & \\
\hline & & $\mathbf{n}$ & $\%$ & $\mathbf{n}$ & $\%$ & $\mathbf{n}$ & $\%$ \\
\hline 1. & Perawat & 11 & 37,93 & 18 & 62,07 & 29 & 100 \\
\hline 2. & Bidan & 9 & 47,37 & 10 & 52,63 & 19 & 100 \\
\hline & Jumlah & 20 & 41,67 & 28 & 58,33 & 48 & 100 \\
\hline
\end{tabular}

Berdasarkan tabel 7 dapat dilihat bahwa tenaga perawat dibandingkan tenaga bidan sebanyak 18 orang perawat $(62,07 \%)$ yang tidak baik dalam hal pemakaian APD.

\section{KESIMPULAN DAN SARAN}

Tenaga perawat dan bidan sebagian besar berumur $20-27$ tahun dengan tingat pendidikan seluruhnya Diploma 3, masa kerja adalah 6 - 12 bulan, dan lama kerja 8 jam/hari.

Macam APD yang disediakan yaitu masker, sarung tangan, jas operasi, tudung/topi, penutup alas kaki, kacamata operasi dan baju pelindung. Pemakaian APD tidak baik pada tenaga perawat.

Saran yang dapat diberikan agar pihak RS menjadualkan penyuluhan secara rutin tentang manfaat APD untuk meningkatkan kesadaran tenaga perawat dan bidan akan pentingnya penggunaan APD dalam bekerja. Perlu pengawasan yang ketat agar tenaga perawat dan bidan disiplin dalam pemakaian APD selama bekerja.

\section{KEPUSTAKAAN}

1. Puslitbang IKM FK UGM dan Program S2 Hiperkes UGM 2000. Kumpulan makalah khusus K3 Rumah Sakit. Fakultas Kedokteran Universitas Gajah Mada, Yogyakarta

2. Harwanti, Nunik. 2009. Pemakaian Alat Pelindung Diri Dalam Memberikan Perlindungan Bagi Tenaga Kerja di Instalasi Rawat Inap I RSUP Dr. Sardjito Yogyakarta. Skripsi, Surakarta

3. Depkes RI, 2003. Indikator Indonesia Sehat 2010 dan Pedoman Penetapan Indikator Provinsi Sehat dan Kabupaten/Kota Sehat, Jakarta

4. Bea, Betty Septiari, 2010. Infeksi Nosokomial. Nuha Medika. Yogyakarta

5. Anwar A, Perwitasari, D. 2006. Tingkat Risiko Pemakaian APD dan Higiene Petugas Laboratorium Klinik RSUPN Ciptomangunkusumo Jakarta. Jurnal 
Ekologi Kesehatan Volume 5 No 1 April 2006.

6. Anawati, Rhomi Kartika, Novitasari, Dwi, Mawardika, Tina. 2013. Hubungan Pengetahuan Dan Sikap Dengan Kepatuhan Perawat Dalam Penggunaan Alat Pelindung Diri

7. International Labour Office (ILO), 1989. Pencegahan Kecelakaan (Seri Manajemen No. 132). PT Pustaka Binaman Pressindo, Jakarta

8. Parkinson, 1982. Health Promotion in The Work Place. Mayfield Publishing Company, California

9. Mulyanti, Dedek, 2008. Faktor Predisposing, Enabling dan Reinforcing terhadap Penggunaan APD dalam Asuhan Persalinan Normal di RS Meuraxa Banda Aceh Tahun 2008. Tesis. Sekolah Pascasarjana Univesitas Sumatera Utara, Medan

10. Notoadmojo, Soekidjo, 2003. Promosi Kesehatan Teori dan Aplikasi. Rineka Cipta, Jakarta

11. Nursalam, 2003. Konsep dan Penerapan Metodologi Penelitian Ilmu Keperawatan. Rineka Cipta, Jakarta

12. Anugraheni, Christina, 2010. Hubungan Faktor Individu dan Organisasi dengan Kepatuhan Perawat dalam Menerapkan Pedoman Patient Safety di RSAB Harapan Kita Jakarta. Tesis. Program Pasca Sarjana Kekhususan Kepemimpinan dan Manajemen Keparawatan, Depok.

13. Anderson, D. P. 1974. Fish Immunology. THF Publication Inc. Ltd, Washington 